\title{
PENAMBAHAN SUSU KEDELAI TERHADAP KUALITAS KEFIR SUSU KAMBING
}

\section{ADDED BY SOYMILK ON QUALITY OF GOAT MILK KEFIR}

\author{
Luki Amar Hendrawati dan Isyunani \\ Dosen STPP Malang \\ luki_amarh@yahoo.com
}

\begin{abstract}
ABSTRAK
Tujuan penelitian untuk mengkaji kualitas kefir susu kambing yang telah diberi perlakuan penggunaan susu kedelai ditinjau dari nilai $\mathrm{pH}$, viskositas, kadar protein, kadar lemak. Hasil penelitian diharapkan dapat memberikan informasi bagi praktisi dan industri tentang kualitas kefir susu kambing sebagai bahan pangan yang dapat menunjang kesehatan. Materi penelitian adalah kefir susu kambing yang diberi perlakuan penambahan susu kedelai sebesar 10\% (P1),20\%(P2) dan 30\%(P3) dan Kontrol kefir susu kambing (P0) dari volume kefir susu kambing. Metode penelitian menggunakan metode percobaan dengan Rancangan Acak Lengkap (RAL). Parameter yang dikaji adalah nilai $\mathrm{pH}$, viskositas, kadar protein,kadar lemak dan total asam kefir susu kambing. Data yang diperoleh dianalisis dengan sidik ragam dan dilanjutkan dengan Uji Jarak Berganda Duncan. Hasil penelitian menunjukkan bahwa penambahan susu kedelai tidak memberikan perbedaan pengaruh yang nyata $(\mathrm{P}>0,05)$ terhadap nilai $\mathrm{pH}$, memberikan perbedaan pengaruh yang sangat nyata $(\mathrm{P}<0,01)$ terhadap nilai viskositas, kadar protein, kadar lemak dan total asam kefir susu kambing. Kesimpulan dari penelitian ini adalah kualitas kefir susu kambing mengalami peningkatan setelah ditambahkan susu kedelai. Semua perlakuan menghasilkan kefir susu kambing yang sesuai standar susu fermentasi.
\end{abstract}

Kata kunci : kefir susu kambing, susu kedelai,

\section{ABSTRACT}

The objectives of the research were to find out the different level effect of the soymilk utilization as $\mathrm{pH}$, viscosity, and chemical quality of kefir and as an information for practician and industry related to the research product. The materials of the research were kefir made from goat milk, with the treatments were the addition of soymilk extract on goat milk kefir at $10 \%(P 1), 20 \%(P 2)$ and 30\% (P3) and kefir goatmilk (P0) concentration levels. The research method was an experiment using Randomized Block Design, with three replication. The variables measured were $\mathrm{pH}$, viscosity, protein, fat and total acid s content of kefir. Data were analyzed by analysis of variance and contimued with Duncan. The result of the research indicated that addition of soymilk had not significant effect $(P>0,05)$ on $\mathrm{pH}$ and that each treatments were given highly significant effect $(P<0,01)$ on protein,fat content of goat milk kefir. The conclusion of this research was addition of soymilk had increase quality of goat milk kefir.

Keywords : goat milk kefir, soymilk

\section{PENDAHULUAN}

Kefir merupakan produk susu fermentasi dapat dibuat dari bahan baku susu sapi, susu kambing atau susu domba dengan menambahkan bibit kefir (kefir grains) yang terdiri dari bakteri asam laktat dan khamir (Kosikwoski, 1982). Struktur 
bibit kefir berlipat lipat pada permukaannya, merupakan penebalan berbagai mikroorganisme, berbentuk tidak teratur dan seluruhnya berwarna putih (Saloff-Coste,1996) Kefir juga dikenal sebagai minuman probiotik, umumnya dibuat dengan jalan melakukan pasteurisasi susu kemudian diinokulasikan dengan kefir grains (bibit kefir) yang berisi kumpulan Bakteri Asam Laktat (Lactobacilli, Lactococci, Lactobacillus kefir, Lactobacillus parakefir, Lactobacillus kefiranofaciens dan Lactobacillus kefirgranum), khamir dan bakteri asam asetat (Anonymous,2007). Kefir berperan sebagai probiotik yang dapat menekan pertumbuhan bakteri penyebab penyakit saluran pencernaan, disamping itu juga bermanfaat bagi kesehatan karena kefir diduga dapat menurunkan kadar kolesterol dalam darah serta meningkatkan High Density Lipoprotein (HDL) (Farnworth,2006). Penggunaan susu kambing sudah popular terutama untuk therapy kesehatan karena kandungan proteinnya yang lebih tinggi dibandingkan susu sapi dimana terdapat 10 asam amino esensial, juga karena alasan bahwa susu kambing mengandung laktosa yang rendah yaitu sekitar $4,1 \%$ dibandingkan susu sapi $4,7 \%$, sehingga susu kambing sesuai bagi penderita Lactose intolerance (Noor,2002). Susu kambing mempunyai banyak kelebihan jika dibandingkan dengan susu sapi antara lain susu kambing lebih cepat terdispersi dan campurannya lebih homogen serta mudah dicerna karena molekul butiran lemaknya lebih kecil yaitu 3,49 mm sedangkan susu sapi 4,55 $\mathrm{mm}$ dan terdiri dari asam lemak berantai pendek dan sedang, tidak mengandung $\beta$ - laktoglobulin yaitu penyebab terjadinya alergi (Anonymous, 2008) yang sering ditimbulkan oleh susu sapi. Sebenarnya susu kambing dapat digunakan sebagai bahan baku dalam pengolahan kefir tetapi mempunyai beberapa kekurangan karena kandungan laktosa dalam susu kambing lebih sedikit dibandingkan susu sapi serta mengandung asam lemak jenuh 64,36 persen J. Ternak Tropika Vol. 12, No.1: 1521, 201117.
Dirasakan hal-hal tersebut dapat diatasi dengan menambahkan susu kedelai sehingga susu kedelai dapat digunakan sebagai sumber makanan bagi BAL dan dapat mengurangi kandungan lemak kefir yang dihasilkan karena kedelai sedikit mengandung asam lemak jenuh dan tidak mengandung cholesterol (Al-Baarri dan Murti, 2003). Karbohidrat dalam susu kedelai berasal dari golongan oligosakarida dan polisakarida, merupakan prebiotik yang terdapat dalam kedelai dan digunakan lebih lanjut oleh mikroorganisme probiotik yang hidup dalam saluran cerna sebagai sumber energy (Harish and Varghese,2006). Kedelai merupakan sumber prebiotik alami karena mengandung karbohidrat jenis galactooligosaccharides (GOS) yang tidak dapat dicerna oleh enzim dalam tubuh manusia tetapi dapat dicerna oleh BAL dengan menggunakan enzim alphagalaktosidase (Martos, 2006). Pati yang terkandung dalam kedelai ini diyakini dapat meningkatkan viskositas (Whistler and Miller,1997).

Susu kedelai mempunyai gizi yang hampir setara dengan susu sapi, umumnya digunakan sebagai pengganti susu sapi bagi penderita Lactose intolerance dan penderita alergi terhadap protein susu sapi (Koswara,2006). Kandungan asam lemak susu kedelai sebagian besar adalah asam lemak tidak jenuh dengan kadar asam linolenat 5-10\%, asam linoleat 43 $56 \%$,asam oleat $15-33 \%$ dan asam lemak jenuh 26\% (Estiasih, 2005). Kefir mempunyai pH sekitar 3,8 - 4,6 disebabkan karena proses fermentasi yang membentuk asam laktat, berperan menurunkan $\mathrm{pH}$ (Oberman and Libudzist, 1998) dan mempengaruhi viskositasnya, dimana viskositas dapat diamati secara absolute maupun relative. Pengukuran secara absolute dengan poise sedangkan pengukuran secara relative didasarkan pada besarnya volume yang dapat mengalir pada waktu tertentu (Rahman, 1992). Tingkat penerimaan konsumen terhadap tekstur makanan tergantung ada viskositas dan konsisitensi produk pangan tersebut (Fennema, 1996). 
Protein yang terkandung dalam produk fermentasi merupakan jumlah total protein susu yang digunakan sebagai bahan baku dan protein bakteribakteri yang terkandung dalam starter. Isoflavon merupakan senyawa flavonoid dalam kedelai merupakan gabungan dari ikatan sejumlah asam amino dengan vitamin dan beberapa zat gizi lain, merupakan senyawa fenol heterosiklik yang strukturnya mirip dengan steroid estrogen (Sofian, 2008). Isoflavon merupakan kunci dalam kedelai sehingga kedelai dianggap dapat memerangi berbagai penyakit antara lain penyakit jantung, mencegah osteoporosis, menanggulangi menaupouse dan sebagai zat anti kanker (Komswara,2006)

Tujuan dari penelitian ini adalah untuk mengkaji kualitas kefir susu kambing yang telah diberi perlakuan dengan penambahan susu kedelai ditinjau dari nilai $\mathrm{pH}$, viskositas, kadar protein,kadar lemak .

\section{METODE PENELITIAN}

Waktu penelitian dilaksanakan pada bulan Juni sampai Oktober 2015. Tempat pelaksanaan penelitian di Laboratorium Teknologi Hasil Ternak STPP Malang.
Materi penelitian adalah kefir yang dibuat dari bahan baku susu kambing, dilakukan penambahan ekstrak susu kedelai. Metode penelitian adalah eksperimental dengan

Rancangan yang digunakan dalam penelitian ini adalah percobaan Rancangan Acak Kelompok dengan 3 perlakuan yaitu:

P1 : penambahan ekstrak susu kedelai $10 \%$ dari volume kefir

P2 : penambahan ekstrak susu kedelai $20 \%$ dari volume kefir

P3 : penambahan ekstrak susu kedelai $30 \%$ dari volume kefir

Parameter yang dikaji adalah nilai $\mathrm{pH}$, viskositas, kadar protein, kadar lemak dan kefir yang dihasilkan. Data yang diperoleh dianalisis dengan sidik ragam dan apabila terdapat perbedaan dilanjutkan dengan Uji Jarak Berganda Duncan (UJBD).

\section{HASIL DAN PEMBAHASAN}

\section{Pengaruh penambahan susu kedelai terhadap nilai pH dan viskositas kefir susu kambing}

Pengaruh penambahan susu kedelai terhadap nilai $\mathrm{pH}$ dan viskositas kefir susu kambing dapat dilihat pada Tabel 1.

Tabel 1. Rata-rata nilai pH dan viskositas (cps) kefir susu kambing

\begin{tabular}{|l|l|l|}
\hline Perlakuan & Rata-rata $\mathrm{pH}$ & Viskositas \\
\hline P0 & 3,91 & 810 \\
\hline P1 & $4,01 \mathrm{a}$ & $740 \mathrm{a}$ \\
\hline P2 & $3,98 \mathrm{~b}$ & $660 \mathrm{~b}$ \\
\hline P3 & $3,91 \mathrm{c}$ & $600 \mathrm{c}$ \\
\hline
\end{tabular}

Sumber: Hasil Laboratorium pengujian mutu dan keamanan pangan (testing laboratory of food quality and food safety) Fakultas Teknologi Pertanian Universitas Brawijaya

Keterangan : perubahan notasi a,b dan c pada kolom yang sama menunjukkan adanya perbedaan pengaruh yang sangat nyata $(\mathrm{P}<0,01)$.

Tabel 1 menunjukkan bahwa susu kedelai dapat berfungsi sebagai prebiotik yang dimanfaatkan oleh BAL sebagai sumber energy dengan menunjukkan peningkatan nilai $\mathrm{pH}$ sejalan dengan penambahan susu kedelai. Peningkatan $\mathrm{pH}$ artinya semakin nilai angkanya rendah semakin tinggi tingkat keasaman.
Yusmarini (2004) menjelaskan bahwa kedelai merupakan sumber karbohidrat yang memiliki susunan oligosakarida dan polisakarida. Kenaikan nilai keasaman $\mathrm{pH}$ kefir pada perlakuan P3 disebabkan tingginya konsentrasi kedelai yang terlarut, sehingga air akan berbalik dari dalam sel mikroorganisme kefir keluar sel, karena tekanan osmosis yang tinggi dan terjadi proses plasmolisis, hal ini menyebabkan penghambatan pertumbuhan mikroorganisme kefir (Aini, Suranto dan 
Ratna, 2003). Semakin banyak penggunaan kedelai, jaringan gel yang terbentuk semakin bertambah yang dapat mengakibatkan terbatasnya ruang gerak BAL dan menyebabkan pertumbuhan BAL kurang optimal. Rata-rata nilai viskositas kefir pada semua perlakuan semakin meningkat sejalan dengan meningkatnya persentase penambahan susu kedelai, menunjukkan perbedaan pengaruh yang sangat nyata $(\mathrm{P}<0,01)$. Meningkatnya penambahan susu kedelai berarti meningkatkan total padatan dan meningkatkan viskositas. Kenaikan $J$. Ternak Tropika Vol. 12, No.1: 15-21, 201119 viskositas dapat dipengaruhi oleh turunnya $\mathrm{pH}$ serta jumlah karbohidrat dan protein yang terkandung dalam kefir. Pengaruh enzim proteolitik dapat memecah ikatan polipeptida menjadi lebih pendek dan protein terdenaturasi membentuk padatan yang lebih kompak

(Aini dkk, 2003)

Pengaruh penambahan susu kedelai terhadap kadar protein, kadar lemak dan kadar isoflavon kefir susu kambing dapat dilihat pada Tabel 2.

Tabel 2. Rata-rata kadar protein(\%), kadar lemak $(\%)$ dan total asam kefir susu kambing

\begin{tabular}{|l|l|l|l|}
\hline $\begin{array}{l}\text { Perlakuan } \\
\text { rata-rata }\end{array}$ & $\begin{array}{l}\text { Kadar } \\
\text { protein }\end{array}$ & $\begin{array}{l}\text { Kadar } \\
\text { lemak }\end{array}$ & $\begin{array}{l}\text { Total } \\
\text { Asam }\end{array}$ \\
\hline P0 & 3,37 & 4,56 & 1,44 \\
\hline P1 & $3,51 \mathrm{a}$ & $5,50 \mathrm{k}$ & $1,43 \mathrm{x}$ \\
\hline P2 & $3,68 \mathrm{~b}$ & 4,761 & $1,42 \mathrm{y}$ \\
\hline P3 & $4,02 \mathrm{c}$ & $4,71 \mathrm{~m}$ & $1,51 \mathrm{z}$ \\
\hline
\end{tabular}

Sumber: Hasil Laboratorium pengujian mutu dan keamanan pangan (testing laboratory of food quality and food safety) Fakultas Teknologi Pertanian Universitas Brawijaya

Keterangan : perubahan notasi $(\mathrm{a}, \mathrm{b}, \mathrm{c}),(\mathrm{k}, \mathrm{l}, \mathrm{m})$ dan $(\mathrm{x}, \mathrm{y}, \mathrm{z})$ pada kolom yang sama menunjukkan adanya perbedaan pengaruh yang sangat nyata $(\mathrm{P}<0,01)$ Tabel 2 menunjukkan bahwa rata-rata kadar protein mengalami peningkatan sejalan dengan penambahan susu kedelai, hal ini disebabkan karena kandungan protein pada ekstrak susu kedelai juga penambahan protein dari mikroba dalam bibit kefir. Yusmarini dan Efendi (2004) menyatakan bahwa protein yang terkandung dalam susu fermentasi merupakan jumlah total dari protein susu bahan baku yang digunakan dan protein bakteri-bakteri yang terkandung di dalamnya. Bakteri mempunyai kandungan protein berkisar antara $40-60$ persen (Sudarmadji dan Kuswanto,1989) dan sel khamir mengandung protein sebesar 40 persen (Buckle et al, 1987). Rata-rata kadar lemak kefir susu kambing mengalami penurunan sejalan dengan peningkatan penambahan susu kedelai, hal ini disebabkan susu kedelai mengandung kadar lemak lebih rendah dibandingkan susu kambing sebagai bahan baku kefir. Otles and Cagindi (2003) menyatakan bahwa kadar lemak kefir tergantung dari kadar lemak bahan baku yang digunakan. Kadar lemak susu kedelai jauh lebih rendah yaitu sebesar 2 persen dari pada kadar lemak susu kambing yang sebesar 4,1 persen (Anonymous, 2007). Semakin meningkat penambahan ekstrak susu kedelai menghasilkan kandungan total asam (asam laktat) dalam kefir susu kambing mengalami peningkatan. dikarenakan kandungan karbohidrat yang ada dalam kedelai dan termasuk tanaman golongan kacang-kacangan, yang berikatan dengan karbohidrat yang disebut isoflavon glycoside. Kedelai merupakan salah satu sumber isoflavon, dengan kandungan antara $0,05-0,3$ persen yang dapat memberikan tambahan nutrisi untuk bakteri asam laktat (Kelly, Huang, Deacon-shaw and Waring, 2006). Adapun secara umum ada standar kandungan kefir susu kambing adalah sbb: Kadar asam laktat $0,8-1,1 \%$, alkohol 0,5$2,5 \%$, sedikit gas karbon dioksida, kelompok vitamin B serta diasetil dan asetaldehid Air 89,5\%, lemak 1,5\%, protein $3,5 \%$, abu $0,6 \%$, laktosa $4,5 \%$ dengan nilai $\mathrm{pH}$ 2- 4,6. Sehingga hasil kefir susu kambing yang sudah ditambah dengan susu kedelai adalah semakin banyak pemberian level susu kedelai maka semakin baik pH, vikositas, kadar proteinnya dan lemaknya serta total asam 
laktat yang dihasilkan secara hasil uji laboratorium.

\section{KESIMPULAN}

1. Penambahan susu kedelai dapat meningkatkan kualitas kefir susu kambing.

2. Penambahan susu kedelai tidak memberikan perbedaan pengaruh pada nilai viskositas dan kadar lemak kefir susu kambing, tetapi memberikan perbedaan pengaruh yang sangat nyata pada nilai $\mathrm{pH}$, kadar protein, dan total asam kefir susu kambing

\section{SARAN}

Sebaiknya dilakukan penelitian lanjutan dengan penambahan susu kedelai pada kefir susu kambing terhadap penyimpanan dalam refrigerator ditinjau dari kualitas fisik,kimiawi dan mikrobiologisnya.

\section{DAFTAR PUSTAKA}

Al-Baarri A,N dan T.W. Murti 2003 Evaluasi Komposisi Kimia Susu Kambing Yang Difortifikasi BAL dengan Kehadiran Ekstrak Susu Kedelai. (http://Milkordie.blogspot.co

Aini, Y.K.,Suranto dan S.Ratna, 2003.Pembuatan Susu Kedelai Dengan Variasi Kadar Susu Skim dan Inokulum. Biosmart vol 5 no $2,89-93$

Anonymous. 2007. Artikel Tentang Kefir. http://www.rekadaya.com/tentang kefir/.

Anonymous. 2008. Susu Segar Kambing Ettawa. http://www.susukambing.net/
Beberapa Jenis Gula. Jurnal Natur AInd. 6 (2) : 104-110

Brooktandle. New York. Koswara, S.2006. Susu Kedelai tak Kalah Dengan Susu Sapi.

E.P.R. 2006. Soybean Oligosaccharides. Potential as New Ingredients in Functional Foods. Departemento de Metabolisme nutricion. Instituto del Frio (CSIC). Madrid Espana. Nutr Hosp; 21 :92- 96. J. Ternak Tropika Vol. 12, No.1: 15-21, 201121

Estiasih, T. 2005. Kimia dan Teknologi Pengolahan Kacangkacangan. Fakultas Teknologi Hasil Pertanian. UB, Malang

Farnworth,E.R.2006. Kefir -A Complex Probiotic. Food Science and Technology Bulletin: Funtional Foods,vol 2,Issue 1(http://www.foodsciencecentral.co $\underline{\mathrm{m}}$.

Harish, K and T. Varghese. 2006. Probiotics in Human -Evidence Based Review. Calicut Med.J. 4(4):e3.pp 1 - 11.

Kelly, G.E., Huang, J.L.,Deacon-shaw, M.G., and Waring, M.A. 2006. Isoflavones Compositions Produced From Legumes. United states Patent 7033621. http://www.freepatentsonline.com/7 033621.html. Diakses tgl 20 April 2009.

Kosikwoski, F.V. 1982. Cheese and Fermented Milk Food. Published by Kosikwoski and Associates.

Kuswanto. 1989. Mikrobiologi Pangan. PAU Pangan dan Gizi UGM, Yogyakarta.

Noor , R.R. 2002. Khasiat Susu dan Daging Kambing. Kompas 12 Oktober 2008, Jakarta. 
Oberman, H and Z. Libudzist. 1998. Fermented Milk on Microbiology of Fermented Foods. Brian Wood, Balckie Academyc and Profesional, London.

Rahman, A.1992. Teknologi Fermentasi Susu. PAU Pangan dan Gizi, Institut Pertanian Bogor.

Saloff-Coste. C.J.1996. Kefir Danone World Newsletter, no 11. Sudarmadji, S dan K.R.
Sofian, F. 2008. Manfaat dan Kandungan Susu Kedelai. http://ferysofian.blogspot.com/

Whistler, R.L. and J.N. B. Miller.1997 Cabohydrate Chemistry For Food Science. Eagen Press, Minessota.

Yusmarini dan Efendi, R. 2004. Evaluasi Mutu Soygurt Yang Dibuat Dengan Penambahan. 